\title{
Endosonography-Guided Diagnosis of Mediastinal Involvement of Plasma Cell Dyscrasia in a Patient
}

\author{
Gokhan Dindar ${ }^{\mathrm{a}, \mathrm{c}}$, Yucel Ustundag ${ }^{\mathrm{a}}$, Tarik Akar ${ }^{\mathrm{a}}$, Taner Babur ${ }^{\mathrm{b}}$
}

\begin{abstract}
Plasma cell dyscrasia (PCD) is a neoplastic disorder which consists in abnormal proliferation of a single plasma cell. Extramedullary PCD usually occurs in the head or neck. It is diagnosed with biopsy which demonstrates clonal plasma cells. Endoscopic ultrasound may be used for diagnosis in case of lesion is in accessible site of body.
\end{abstract}

Keywords: Plasma cell dyscrasia; Endoscopic ultrasound; Mediastinal lympadenopathy

\section{Introduction}

Plasma cell dyscrasias (PCDs) are characterized by the neoplastic proliferation of a single clone of plasma cells. Extramedullary PCDs are plasma cell tumors that arise outside of the bone marrow. These solitary lesions are most often located in the head and neck regions but also can be found in gastrointestinal tract, urinary bladder, thyroid, breast, lymph nodes and skin $[1,2]$. The diagnosis of an extramedullary PCD requires the followings: biopsy proven extramedullary tumor with evidence of clonal plasma cells, bone marrow aspirate and biopsy must contain no clonal plasma cells, there is no anemia (hemoglobulin $<10 \mathrm{~g} / \mathrm{dL}$ ), hypercalcemia or renal insufficiency (creatinine $>2 \mathrm{mg} / \mathrm{dL}$ ) that could be attributed to clonal plasma cell proliferation and spine and pelvic imagining study must show no lytic lesions [3].

\footnotetext{
Manuscript accepted for publication January 24, 2014

${ }^{\mathrm{a}}$ Department of Gastroenterology, Bulent Ecevit University School of Medicine, Zonguldak, Turkey

${ }^{\mathrm{b}}$ Department of Internal Medicine, Bulent Ecevit University School of Medicine, Zonguldak, Turkey

${ }^{\mathrm{c} C}$ Corresponding author: Gokhan Dindar, Department of Gastroenterology, Bulent Ecevit University School of Medicine, Zonguldak, Turkey. Email: dindar78@yahoo.com
}

doi: http://dx.doi.org/10.14740/jmc1674w

\section{Case Report}

A 73-year-old man with the complaints of back pain and dyspnea was admitted to our clinics. His past medical history included chronic hepatits B, ischemic heart disease and heart failure. Physical examination was normal except with diffuse pulmonary sonor rhonchi. Laboratory studies revealed normochromic anemia (hemoglobin: $11.3 \mathrm{~g} / \mathrm{dL}$ ), decreased albumin/globulin ratio $2.6 / 5.1 \mathrm{~g} / \mathrm{dL}$, high serum immunoglobulin $\mathrm{G}$ and increased urine monoclonal lambda protein levels $42.6 \mathrm{mg} / \mathrm{dL}$ (normal range $8-16 \mathrm{mg} / \mathrm{dL}$ ) and 31.8 $\mathrm{mg} / \mathrm{dL}$ (normal range $3-7 \mathrm{mg} / \mathrm{dL}$ ), respectively. Serum and urine electrophoresis and immunofixation graphs are shown in Figure 1A. Erythrocyte sedimentation rate was $83 / \mathrm{h}$. Bone marrow aspiration and biopsy examinations were normal with regard to the number of plasma cells and there was no abnormality in peripheral blood flow cytometry evaluation. Chest X-ray revealed a minute amount of right pleural effusion in the costophrenic sinus. Thoracic CT revealed pretracheal, right hilar and subcarinal lymph adenopathies of $14 \mathrm{~mm}, 12 \mathrm{~mm}$ and $20 \mathrm{~mm}$ in size, respectively (Fig. 1B). Subcarinal lymp adenopathy was sampled by endoscopic ultrasound (EUS) guided fine-needle aspiration (Fig. 1C). Immune cytochemistry diagnosed plasma cellular dyscrasia (Fig. 1D). Therefore, an extramedullary PCD involving mediastinum was diagnosed in that case.

\section{Discussion}

Plasma cell neoplasm can be classified into the following types: multiple myeloma (bone marrow and other systemic involvements), solitary myeloma (bone plasmacytoma), extramedullary (soft tissue) plasmacytoma (EMP) and plasmablastic sarcoma. Extramedullary PCD, which belongs to the category of non-Hodgkin's lymphoma, is present in about $3 \%$ of all plasma cell neoplasms [4]. Extramedullary PCD occurs when there is soft tissue infiltration of clonal plasma cells. There should be no evidence of bone destruction or occult disease elsewhere [5]. Less than one-quarter of patients have evidence of a low level of monoclonal protein in serum 


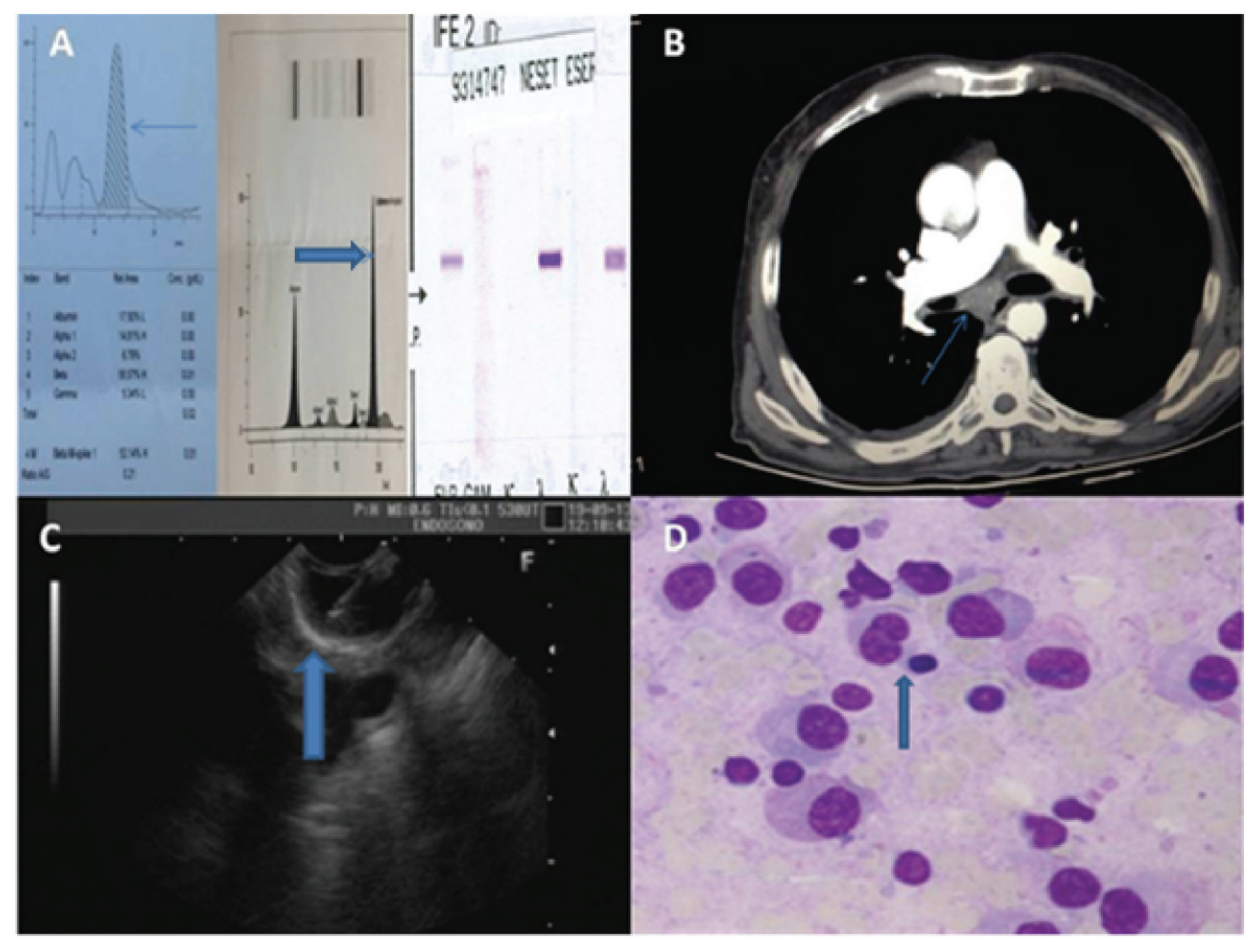

Figure 1. (A) Detection of monoclonal proteins on beta-globulin area (arrow) in urine protein electrophoresis and paraprotein bands on gamma-globulin area (closed arrow) in serum protein electrophoresis. (B) The tomography image of subcarinal lympadenopathy (arrow). (C) Endosonography-guided sampling of lympadenopathy( arrow).

(D) Clonal expansion of plasma cells (arrow).

or urine by electrophoresis and/or immunofixation [6]. EMP affects males 3-4 times more often than females, with an average age of 55. However, one-third of patients with EMP are under 50 years old [7]. Diagnosis of undetermined pulmonary nodular lesions can be accomplished by transbronchial, CT- or sono-guided needle biopsy, as well as surgical biopsy through the VATS or open thoracotomy [8]. However, as in our patient, if target lesion is accessible, EUS can be used to perform sampling. Extramedullary PCDs are highly radiosensitive with nearly all patients successfully achieving local control $(80-100 \%)$ and approximately $50-65 \%$ of patients remaining free of disease longer than 10 years [9].

EUS is a combination of endoscopy and ultrasonography. It is an effective and safe method of examining the posterior mediastinum, inferior mediastinum and paraesophageal regions [10]. It is minimally invasive, painless, does not require general anestesia and can easily be performed on outpatients basis, so that for mediastinal abnormalities (lympadenopathy or mass), EUS-guided fine-needle aspiration could be the first method when target lesion is accessible.

\section{References}

1. Jaffe ES, Harris NL, Stein H, Vardiman JW (Eds), World Health Organization Classification of Tumours. Pathol- ogy and Genetics of Tumours of Haematopoietic and Lymphoid Tissues: IARC Press, Lyon 2001.

2. Soutar R, Lucraft H, Jackson G, Reece A, Bird J, Low E, Samson D. Guidelines on the diagnosis and management of solitary plasmacytoma of bone and solitary extramedullary plasmacytoma. Br J Haematol. 2004;124(6):717726.

3. Criteria for the classification of monoclonal gammopathies, multiple myeloma and related disorders: a report of the International Myeloma Working Group. Br J Haematol. 2003;121(5):749-757.

4. Fanning SR, Hussain MA, Perez-Zincer F. Plasmacytoma, extramedullary. Emedicine. 2006.

5. Dimopoulos MA, Hamilos G. Solitary bone plasmacytoma and extramedullary plasmacytoma. Curr Treat Options Oncol. 2002;3(3):255-259.

6. Liebross RH, Ha CS, Cox JD, Weber D, Delasalle K, Alexanian R. Clinical course of solitary extramedullary plasmacytoma. Radiother Oncol. 1999;52(3):245-249.

7. Galieni P, Cavo M, Pulsoni A, Avvisati G, Bigazzi C, Neri S, Caliceti U, et al. Clinical outcome of extramedullary plasmacytoma. Haematologica. 2000;85(1):4751.

8. Miller DL. Management of the subcentimeter pulmonary nodule. Semin Thorac Cardiovasc Surg. 2002;14(3):281285. 
9. Tsang RW, Gospodarowicz MK, Pintilie M, Bezjak A, Wells W, Hodgson DC, Stewart AK. Solitary plasmacytoma treated with radiotherapy: impact of tumor size on outcome. Int J Radiat Oncol Biol Phys. 2001;50(1):113-
120.

10. DiMagno EP, Buxton JL, Regan PT, Hattery RR, Wilson DA, Suarez JR, Green PS. Ultrasonic endoscope. Lancet. 1980;1(8169):629-631. 